\title{
Neo-Hindu Fundamentalism Challenging the Secular and Pluralistic Indian State ${ }^{\dagger}$
}

\author{
Gino Battaglia \\ Writer and essayist, independent researcher; Clarence Terrace, Penzance TR18 2PZ, Cornwall, UK; \\ ginobat@hotmail.com \\ t This article benefited from the assistance of George Kuscow who reviewed the text with great care \\ and sympathy.
}

Received: 29 August 2017; Accepted: 25 September 2017; Published: 3 October 2017

\begin{abstract}
Secularism seems to require separation between religion and State. Regarding India, it would be better to speak of 'equidistance' between State and religious denominations. Nonetheless a 'balanced treatment' towards the religions leaves the question open as to what form that equidistance should take. This is the reason of some contradictions in today's Indian social and political life. It is likely that without the Moghul and British domination Hinduism would not have acquired a militant identity. It was the 'epiphany' of well-armed, powerful 'Others' (Muslim, Christian or secular) which generated frustration and fear to such an extent that a religious nationalism (Hindutva) was born. Nehru and the Left of the Congress Party leadership thought that modernity would overcome religion, which is a remnant of the past. They were confident that a political culture based on pluralism and tolerance would become the foundations of the new society. This is exactly what Hindu Nationalism takes issue with: the 'pseudo-seculars' project of building the national identity without Hinduism or against Hinduism. Hindutva asserts that Hinduism is the basis of the Indian civilization. The Hindu ethos is the soul of the nation.
\end{abstract}

Keywords: Hindu Nationalism; Hinduism; Hindutva; India; Fundamentalism; secularism; religion and violence; State and religion

\section{Introduction}

While Pakistan came into being the 'land of the pure' (the country of the Subcontinent's Muslims), the new India was born a secular country. "A sovereign democratic Republic", as was written into the Preamble to the Constitution. In 1976 were added "socialist" and "secular". Thus it became "a sovereign socialist secular democratic Republic". India was (and is) plural, its population a countless mix of ethnic groups, languages and traditions. The subcontinent was never a unified kingdom or nation before independence, thus there were plenty of large and small states together with different empires. Just about all the great world religions are present in India. Hinduism, Sikhism, Jainism, Buddhism are indigenous to that land. Today, India retains the third largest Muslim population on the planet. ${ }^{1}$ India's huge Christian minority consists of various denominations comprising different rites. ${ }^{2}$ Small Jewish communities are scattered to remote corners of the country. In central India a Zoroastrian community is present and influential. During the whole colonial era and in particular the 20th century, new religions, Christian denominations and various cults have taken root: Bahá'i,

\footnotetext{
Millions of Muslims, many more than those who migrated, remained in India after the Partition.

2 Syro-Malabar Church (catholic, East Syrian Rite), Syro-Malankara Church (catholic as well, West Syrian Rite), Malankara Orthodox Syrian Church, Catholic Church (Latin Rite), and so on. Some of them (the so called Saint Thomas Christians) might have been there since sub-apostolic age.
} 
established Protestant Churches, neo-Pentecostal movements, Muslim fundamentalist movements, and naturally all the neo-Hindu movements and sects. Shashi Tharoor wrote: "Many observers have been astonished by India's survival as pluralist state. But India could hardly have survived as anything else. Pluralism is a reality that emerges from the very nature of the country; it is a choice made inevitable by India's geography and reaffirmed by its history." (Tharoor 1997, p. 9).

Unity in diversity is an 'Idea of India' and was a challenge to the newly empowered Indian ruling class. Sarvepalli Radhakrishnan identifying secularism with tolerance and impartiality advocated that principle of unity in diversity. Nehru's political project and dream was unity in diversity. Nowadays, co-existence among different religious communities is questioned as a matter of grave concern by Indians themselves. A kind of Hindu Fundamentalism, with its roots in 1920s, took to task the model of secular pluralism nurtured by the body politics of the Indian National Congress (INC). Most commentators describe it as 'Hindu Nationalism', or 'Hindu Politics', or Hindutva, from the title of the most important book by its inspirer Vinayak Damodar Savarkar (1883-1966). Hindutva translates as 'Hinduness' or 'Being Hindu'.

Enzo Pace argues that fundamentalism itself is a form of nationalism (Pace 2009). Religions 'go to war' when they become "the public language of the identity politics", that is to say the repertoire of the symbols which speaks of the other, the 'Enemy' (Pace 2004). Strictly speaking, fundamentalism is a label that refers to the tendency to claim the unerring nature of a sacred text and to deduce from that text a strategy for social action (see Almond et al. 2003): the ultimate goal is to achieve utopia of a "regime of the truth" (Pace and Guolo 2002). Once in power, fundamentalist movements aim at rebuilding what relativism and secularism have jeopardized, the religion social function of integration. Malise Ruthven asserts that fundamentalism and nationalism have a "tortuous relationship" (Ruthven 2007). What I shall therefore assert is that Hindutva has very little to do with religion while it has much to do with politics and with the struggle for power and wealth.

In order to proceed we must define the concept of secularism in contemporary India. The concept of secularism and the secular is complex. For sure in the Indian social, political and cultural context the terms secularism and secular, laicism and lay need some clarification (see Smith 1963; Srikanth 1994; Basu and Subrahmanyam 1996; Madan 1998; van der Veer 2000; Zakarya 2002; Tejani 2008). The so-called Indian secularism has nothing to do with the Italian secolarismo or French laïcité (the exclusion of every religious symbol from public life in order to confine religion to people's private lives). The exact opposite is the case in India. There are different models of relationship between State and religion. A comprehensive account of the set of issues concerning secularism is available in the work of Paolo Naso, L'incognita post-secolare (Naso 2015), ${ }^{3}$ but none of the models he analyses seems to fit contemporary India. Such models are related to a specific field of research, Europe and the Mediterranean area. H. Srikanth groups the different interpretations of secularism in India under three traditions-rational secular tradition, Indian secular tradition and Hindu communal

3 The Author analyzes the different models of relationship between states and religious denominations, partially following Brugger (Brugger 2009): (i) relation of "rivalry or hostility" (see the attitude of some regimes inspired by Marxist-Leninist ideology towards religion), when the State has no relationships with the religious denominations and considers them a threat, and therefore restricts the expressions of belief and religious public activities, in whole or in part, or persecutes religions and their faithful; (ii) "strict separation", when the State has no relationships with the religious denominations, and any sign of religious identity or belonging is restricted to the private sphere (see contemporary France or Atatürk's Turkey); (iii) "separation and consideration", when the State recognizes the relevance of the religious denominations, has institutional relations with them, although it does not subsidize them (it is the case of the USA, e.g.)); (iv) "division and partial cooperation"; when the State recognizes the social function of the religions and has several modalities of relation available, while it cooperates with religions in some areas (Germany, e.g.)); (v) "formal unity", when the State privileges a religious denomination which may assume institutional roles (it is the case of Anglican Church in the UK or Orthodox Church in Greece); (vi) "material unity", as in the case of Islamic states ruled by Shari'a, when the State privileges a religious denomination whose principles become law of the State itself. 
tradition- ${ }^{4}$ since no one in India will admit to the communal character of the ideology or politics they follow (Srikanth 1994).

\section{Indian Secularism}

Amartya Sen's essay on Indian secularism still holds up after two decades (Sen 2005). Secularism requires separation between religion and State and no State interference in religious matters. But there are different degrees of separation. Sen prefers to speak about "equidistance" between State and all the religious denominations. He writes:

What is needed is to make sure that, in so far as the state has to deal with different religions and members of different religious communities, there must be a basic symmetry of treatment. In this view, there would be no violation of secularism for a state to protect everyone's right to worship as he or she chooses, even though in doing this the state has to work with—and for-religious community (Sen 2005, p. 296).

Thus Sen, on the same path of Radhakrishnan, emphasizes symmetry rather than separation. Which in theory has been the prevalent Indian perspective since Independence until the electoral success of Hindu Nationalism and its growing influence in society. If the State is capable of granting freedom of worship, even through its cooperation with various religious communities, then it is no less secular, as long as symmetry and equidistance is preserved. Nonetheless balanced treatment leaves the question open as to what form that symmetry should take. Should the State forbid anything that might offend a particular religious community? The slaughter of cows for example? Is a particular Civil Code needed for each religious community according to its own religious principles? Shari'a law already exists and is widely accepted in India while a secular common Civil Code was introduced for the rest of the population. Some accommodations designed to suit minority might be incompatible with secularism, while others might risk dire consequences. Sen states: "In analyzing the role of secularism in India, note must be taken of its intrinsic 'incompleteness', including the problems that this incompleteness leads to, as well as the opportunities it offers" (Sen 2005, p. 297). Certain developments might help us to define the incompleteness of Indian secularism. Let us consider three issues: federalism and the linguistic issue, positive discrimination vs. secularism, castes and politics.

\subsection{Federalism and the Linguistic Issue}

In India local identity and national identity ${ }^{5}$ are not incompatible but complementary. Balraj Puri wrote about a "symbiotical, and not dichotomous, relation" between national and sub-national identities (Puri 1987). European nationalisms developed as a result to myths of racial, cultural, linguistic, religious homogeneity. In the Indian mindset diverse identities coexist to different degrees of intensity, such as religious belonging, caste identification, local connection, social reference, and so on. Thus, beside local identity (whose fundamental element is the language), there is another identity, the Pan-Indian identity, which has proved to be ambiguous, deceptive, puzzling and lacks an historical and political anchor. Nonetheless the nationalist and anti-colonial movement revealed the power of that Idea of India.

Independent India managed a complex process of federalism enhancement: adjustments were made and even in recent times new states were created. ${ }^{6}$ In 1955 the Commission set up to study the

4 The rational secular tradition has Western origins. The Indian secular tradition begins with the Indian reformers who identified God with Truth and religion with ethic and so preached a universal religion of tolerance, calling it secularism. Gandhi too can be enrolled in the ranks of the Indian secularists. We will see that there is even a Hindu communal tradition whose representatives claim to be the genuine secularists.

5 It is well known that modern India is a federation of states: I will use the adjective 'national' to refer to the federal level and 'local' (or 'sub-national' or 'regional') to refer to the single states level.

6 In 2000 Uttarakhand and Chhattisgarh and in 2014 Telangana were created. 
reorganization of the states of the Indian Union delivered its report. The States Reorganization Act followed as the 7th amendment to the Constitution. The unifying criterion for the definition of the States borders was the language. Such federal layout, on a cultural basis, opened two further problems: the question of Hindi as national language and the political impact of the exceptions to that rule.

Hindi derives from Sanskrit, and this has to do with several unsolved problems for the new nation: the Indian identity as Hindu identity; the historical and cultural division between the Sanskritic North and the Dravidic South and the impossibility of making Sanskrit and its literature the cultural matrix of whole India. So the standard Hindi (which was adapted from the Delhi area dialect), although used in public speeches and official documents, never ranked as a common national language. Rather, English became the koinè for the educated.

However local identity is connected to the communal identity. There have been some de facto exceptions to the principle of States creation: the creation of Nagaland in the far North-East (1963) on an ethnic-tribal-basis, also a religious basis, the majority of population being Christian; the creation of Punjab (1966) on the basis of a common shared language, plus a religious basis, being Punjab the land of the Sikhs. These two States have endured considerable unrest; both had strong and sometimes violent separatist movements. Along with them Kashmir, the state with a Muslim majority at the center of the conflict between India and Pakistan, has had a separatist movement since the 1980s. Therefore some Indians (certainly many Hindus) might think the federal-secular order has been under attack on religious basis.

\subsection{Positive Discrimination and Secularism}

During the 1980s and 1990s alarm spread throughout India: Hindus were being discriminated against, while the chance to live according to one's religion principles was granted to everyone else. Equidistance and symmetry of the State towards the religions was under question. The Constitution states that all citizens of India are equal, that is to say the population is composed of individuals, not groups (castes, tribes, social classes, ethnic groups or religious communities). But the fulfillment of those principles has not always been consistent. A complete separation between State and religious denominations was not thinkable, therefore not possible in India. Ultimately a sort of pragmatism prevailed, yet while going some way to solving the problem, it created another one (see Swamy 2006). Separate negotiations with individual religious communities were initiated. The various governments had to deal with the different degrees of willingness of the religious communities. Indian Muslims were allowed to keep their Civil Code based on Shari'a, while Hindu civil law was reformed, hoping that the Civil Code would become the common Code for all the Indians. The Caste system and untouchability were abolished in keeping with the Constitution that banished any discrimination, even in private life, such as social exclusion, restriction of access to shops, restaurants, cinemas, places of amusement, streets, public places, wells, water tanks, ghats. The aim was to remove or modify habits, amend old customs and religious norms in order to achieve a modern rule of law where all the citizens could actually be equal. But where exactly is the fault line between good will and positive intervention of the State to remove discrimination from public life and de facto interference in religious communities' life? Moreover, a policy aimed at benefiting some social groups, often religious groups, risks stressing differences instead of removing them.

The Indian sociologist Partha Chatterjee, not a nationalist sympathizer, remarked that the principle of equality has been infringed when the State chooses to interfere in matters regarding the Hindu majority, while deferring actions when it comes to other religious communities indefinitely (Chatterjee 1997, p. 244). Even exponents of the Left in opposition did not deem it worthwhile to proceed with a policy that was so partial. Neither was Nehru's reasoning persuasive, that the Muslims were not ready for such a reform. 


\subsection{The Caste System and Politics}

The Caste system was the major challenge for the new nation. It is surprising that despite the castes democracy survived in India, even more surprising the fact democracy succeeded thanks to the castes (d'Orazi Flavoni 2000, pp. 173-85).

The origins of the Caste system lie in Indian civilization rather than in religion. ${ }^{7}$ It is significant in fact that castes persist in other Indian religious communities: not exclusively among Hindus but also among Sikhs, just as they do among Christians or Muslims. The Caste System is a tangible institution in Indian civilization. It has acquired the features of a psyche, a way of thinking, a mindset, an existential frame. So it cannot be modified by some reforms. The strength of Caste system can be understood if one takes into account the traditional weakness of the institutions that contributed to the birth of European nations: the State and the Church. India being a vast rural world, made up of thousands hamlets, the 'State' has always been remote and its actions sporadic and contradictory. Dr. Ambedkar used to say: "Our Gram Panchayats [village councils] were so strong that we forgot Delhi's throne." In a context where even war was a privilege for certain ethnic groups or castes, the point of reference for the individuals remained the castes. Regarding a unitary and homogeneous religious institution, it never existed in India. ${ }^{8}$

Thus the Caste System (together with its main abomination, the untouchability) is not only an unjust social custom: the system is based on a metaphysic. It has to do with Dharma and swadharma, ${ }^{9}$ karma and samsara. The social effects might appear archaic and unfair, but caste provides a set of duties to the individuals and compatible roles to groups. While Mahatma Gandhi considered the Caste system an ethic problem, Dr. Ambedkar considered it a political issue, Pandit Nehru and the progressives within INC had a different perspective. They thought that the castes would disappear thanks to the success of democracy and the old way of thinking would be substituted by a more mature political consciousness. However what actually happened was that castes became aware of their electoral clout and aware of the possibility of having their interests recognized. So here is the ostensible paradox: the most anti-democratic institution was instrumental in the growth of democracy. Indian electoral democracy has been strengthened by the Caste system because castes can hope to have their interests safeguarded by the political process.

\section{Indian Fundamentalism}

What we call Hinduism is hard to define. From an historical perspective it would be better to talk of Hinduisms. Every attempt at an all-encompassing concept will therefore produce vague and inadequate ideas. Hinduism as a single religion among the others, with a precise historical identity, a clear doctrine and a single hierarchy is, as a matter of fact, the opposite of the concept of Sanatana Dharma (universal and eternal Truth) which in the subcontinent has been nurtured for millennia. Nonetheless the comprehension of what Hinduism is, has been a decisive issue for the West and for

7 The hypothesis about historical origins of the castes are well known: Indian civilization was born from a grafting of an alien Aryan population into native Dravidic stump. Castes would have ratified social hierarchy of conquerors and conquered. Ethnic division became social order.

8 Instead there existed a class of priests with worship functions with many connections: local, sectarian, congregational, related to different schools or different clans. We can say the same for the monastic world: it is fragmented in very many orders, schools and ashrams. A complex sacred 'geography' existed and subsists, made of sanctuaries, shrines, holy cities, rivers, mountains and places, sacred animals, with a religious calendar marked by festivals, pilgrimages, religious feasts, with different frequency during the year, or the years. Not a single center therefore. Many centers instead and many reference points. The great master Shankara established four sanctuaries, at the four cardinal points of the sub-continent, with four masters of Advaita doctrine, the shankaracharyas but the latter, with all their authority, are not the highest instance of Hinduism. There are no higher instances in Hinduism. There are vice versa many masters, many pandits, errant monks, eremites, seers, yogis. There are many gurus and each one chooses his/her guru or they are mysteriously chosen by him, although the genuine guru is Brahman.

9 Individual dharma. 
Indians themselves: for a long time in fact Indians have pondered what it is to be an Indian and discussed their own cultural and spiritual identity.

\subsection{What is Hinduism?}

The academic debate about Sanskritization and Brahmanization of Hinduism is well known. ${ }^{10}$ They are longue durée processes which have endured since Vedas along two principal lines: (a) subsuming any different and earlier sacred literature, particular myth, local cult, or religious form into the Vedic religion, as if those diverse religious expressions came from the same environment; (b) linking religion and society, metaphysics and social life through, on one hand, the Advaita philosophy (non duality) and, on the other hand, via the castes and the Caste system. The two perspectives tend eventually to merge (Catalano 2009). Hindutva seems to be the contemporary form of that hegemonic design aimed at all aspects of Indian society and culture.

To conclude that Hinduism is solely a European or western invention ends up being a simplification. Thus, how are we to consider Hinduism? Only an empty word? Too simplistic. A religious system? Too reductive. Or, rather a religious universe in which many different religions were born, live and die? Thus a specific culture? That is the crucial point. It is no coincidence that V.D. Savarkar devoted the first section of his pamphlet Hindutva: Who is a Hindu? To the issue he argued that Hindu identity is not a religious matter. "Hinduism is only a derivate, a fraction, a part of Hindutva", he wrote. (Savarkar [1923] 2005, p. 3). Actually, the common identity of the inhabitants of Hindustan is Hindutva ('Hinduness').

Hinduism is a tradition, a civilization, a History. Hindus are a Nation, Savarkar wrote.

\subsection{Hindutva: Who We Are? Who is a Hindu?}

Lal Krishna Advani, a remarkable exponent of the Hindutva movement, stated in his autobiography that Hindutva is the answer to the question: who are we? (Advani 2008, p. 862). "If India is de-Hinduized, there will be no India left anymore" (Advani 2008, p. 864).

Savarkar was a complicated figure: thinker, political activist, anti-British nationalist, poet, playwright and maybe atheist. He stood against the Caste system and for the return of all Indians converted to any other religions. He created the word Hindutva with the intention of defining a common Indian identity. According to Savarkar a Hindu is an inhabitant of Bharatwarsha, the Hindu Rashtra, the kingdom of the mythical Emperor Bharata. Being Hindu is much more than a religious identity, notwithstanding ethnic and cultural differences between Aryans or Dravidians: one is the "race", one is the jati (lineage), the Hindus. Sons of the common Fatherland, they recognize and worship it as their holy land, "the best nation of Aryans", the eternal Sindhustan (later Hindustan). That is not only a geographical entity but also a nation. In the same 'Holy Land' various peoples and different religions, united by the same blood, have flourished. The same blood, the same language and culture, the shared history of resistance to invaders, the same common laws and rites which unite them all.

To this category of names which have been to mankind a subtle source of life and inspiration belongs the word Hindutva, the essential nature and significance of which we have to investigate into. The ideas and ideals, the systems and societies, the thoughts and sentiments which have centered round this name are so varied and rich, so powerful and so subtle, so elusive and yet so vivid that the term Hindutva defies all attempts at analysis. Forty centuries, if not more, had been at work to mold it as it is. Prophets and poets, lawyers and law-givers, heroes and historians, have thought, lived, fought and died just to have it spelled thus. For indeed, is it not the resultant of countless actions-now conflicting,

10 Roberto Catalano is author of an essay, rich of useful references, devoted to the more recent advancements of the discussion (Catalano 2009). 
now commingling, now cooperating-of our whole race? Hindutva is not a word but a history (Savarkar [1923] 2005, p. 3).

Hindustan had to overcome not only a single people, race or nation, but the whole of Asia and almost the whole of Europe. Hindus fought to safeguard their own civilization, not just for the sake of their religion. Another aspect of Hindu identity is common laws and rites: that is religious festivals, pilgrimages, holy places, customs and traditions. To Savarkar they have the greatest value: they are the 'institutions' of that civilization. They unite the sacred family of religions born to India. Muslims and Christians cannot be recognized as children of the Hindu race because they have other customs, other holy lands, other festivals, other laws. They have been converted by the sword and torn up from their rightful heritage. As a matter of fact they maintain their own Caste System. But their love is divided and their loyalty is dubious.

This way Hindutva challenges the pluralistic and secular India: affirming the original homogeneity of Indians to be enhanced and promoted. According to Hindutva doctrine, such a primeval uniformity of Hindus is not an ideological assertion or a political project but a cultural legacy. That is a metaphysical and meta-historic vision, which is also the root of chauvinism and bigotry in Indian society.

\subsection{The RSS}

The largest organization of Hindu nationalist movement is Rashtriya Swayamsevak Sangh (RSS) ${ }^{11}$ (see Goyal 1979; Andersen and Damle 1987; Kanungo 2002; Chitkara 2004). The RSS was founded in 1925 by Keshav Baliram Hedgewar (1889-1940), known as Doctor-ji by his acolytes, Supreme Leader (Sarsanghachalak) for 15 years. Communal riots often (at that time just as nowadays) broke out on the occasion of religious festivals: celebrations and processions providing an opportunity for mutual provocation. In 1923 a clash between Muslims and Hindus took place in Nagpur, Hedgewar town. It seems likely that incident spurred him into creating a new organization. Four years later under similar circumstances, witnesses reported him playing a drum leading a precession passing by a mosque. The Muslims reacted and the Hindus reacted in turn, resulting in 22 deaths and more than a hundred injured. The Government sent in troops to stop the violence but the RSS militants had already deployed to Hindu areas. It was the Sangh's baptism of fire. Christophe Jaffrelot notes that the RSS played the role of an ideological akhara, ${ }^{12}$ prepared for conflict, attracting violent elements in society, replacing the old organizations like Hindu Mahasabha or the Bengali secret societies (Jaffrelot 1999, pp. 40-41). Since then RSS has been growing in numbers and popularity.

Hedgewar founded the Sangh on Dussehra, the festival which celebrates Rama's victory over the demon Ravana: his aim was the "cultural and spiritual regeneration" of the Hindu Community. Hoping that such regeneration might serve as a means to achieve freedom from British domination. Many hold that Swami Vivekananda and Sri Aurobindo were Hedgewar's inspirers. Under the influence of Savarkar and Bal Gangadhar Tilak, he argued that the Hindu cultural and religious legacy would have been the essence of independent India national identity.

The Hindu culture is the life-breath of Hindustan. It is therefore clear that if Hindustan is to be protected, we should first nourish the Hindu culture. If the Hindu culture perishes in Hindustan itself, and if the Hindu society ceases to exist, it will hardly be appropriate to refer to the mere geographical entity that remains as Hindustan. Mere geographical lumps do not make a nation. The entire society should be in such a vigilant and organized condition that no one would dare to cast an evil eye on any of our points of honor. Strength, it should be remembered, comes only through organization. It is therefore the duty of

11 The National (or Patriotic) Volunteer Organisation.

12 Group or club for training of martial arts. 
every Hindu to do his best to consolidate Hindu society. The Sangh is just carrying out this supreme task (quoted in Kumar and Muralidhar 1997, pp. 23-24).

Doctor-ji died in 1940. Madhav Sadashiv Golwalkar (1906-1973), known as Sri Guru-ji, became Supreme Leader. Under his guidance the RSS grew dramatically to become a mass movement of hundreds of thousands of militants with thousands of sections all over the nation (see Sharma 2007). As Supreme Leader he travelled across the whole of India creating a network of associations that later merged into the Sangh Parivar, the 'Family', made-up of trade unions, economic syndicates, welfare centers, women's organizations, religious congregations, schools and educational institutions, News Agencies, Think Tanks, associations for Indians abroad, for marginalized groups, societies for the promotion of Sanskrit, or for the involvement of Hindus in the military, sports and children's associations, political parties and so on. All led by the RSS.

Those who criticize Golwalkar see him as a Nazi sympathizer. Just as Savarkar and Hedgewar appeared bewitched by totalitarian regimes, he was enthralled by the Fascist regime's capacity for mobilizing populations, imposing military discipline, restoring social order, and promoting and enhancing of virile and pugnacious virtues. Certain statements of his are undoubtedly alarming. He wrote in We, Our Nationhood Defined:

To keep up the purity of the Race and its culture, Germany shocked the world by her purging the country of the Semitic Races-the Jews. Race pride at its highest has been manifested here. Germany has also shown how well-nigh impossible it is for Races and cultures, having differences going to the root, to be assimilated into one united whole, a good lesson for us in Hindustan to learn and profit by (Golwalkar 1939, pp. 87-88).

Jaffrelot writes that Golwalkar, just like Savarkar had, used the word "race", as a translation of the Sanskrit word jati. Here he is more interested in cultural unity than in racial homogeneity (Jaffrelot 1999, p. 57). Such a cultural unity is an equivalent of the German Volksgeist. Golwalkar's racism takes the form of socio-cultural domination rather than being based only on biological claims of superiority or being obsessed with racial purity. Savarkar too wrote about "blood", but for him that was a metaphysical notion rather than a biological one. Therefore the minorities must be 'assimilated' through the removal of any sign of 'stranger' belonging. Hindu symbols are national symbols while those of the minorities are alien. The ideal society according to Golwalkar is a Hindu dominated hierarchy.

Fiercely unfavorable to an idea of secular India he wrote:

There are only two courses open to the foreign elements, either to merge themselves in the national race and adopt its culture, or to live at its mercy so long as the national race may allow them to do so and to quit the country at the sweet will of the national race. That is the only sound view on the minorities' problem. That is the only logical and correct solution. That alone keeps the national life healthy and undisturbed. That alone keeps the Nation safe from the danger of a cancer developing into its body politic of the creation of a state within the state. From this standpoint, sanctioned by the experience of shrewd old nations, the foreign races in Hindustan must either adopt the Hindu culture and language, must learn to respect and hold in reverence Hindu religion, must entertain no idea but those of the glorification of the Hindu race and culture, i.e., of the Hindu nation and must lose their separate existence to merge in the Hindu race, or may stay in the country, wholly subordinated to the Hindu Nation, claiming nothing, deserving no privileges, far less any preferential treatment—not even citizen's rights (Golwalkar 1939, pp. 104-5).

\subsection{The Sangh Parivar Grows}

The growth of Hindu Nationalism organizations has been impressive. The RSS came into being in 1925. In 1932 it had 10,000 members. By 1951 600,000. In 1999 two million along with 40,000 centers 
all over India. Today there are 5 to 6 million members with almost 60,000 centers. In 1964 the Vishva Hindu Parishad (VHP) ${ }^{13}$ was founded in Bombay with the purpose of involving the milieu of the sadus and samnyasins in RSS campaigns and initiatives, giving them an increasing religious character. Thirty years later the VHP had 3000 local sections and 100,000 members. In 1966, once again in Bombay, Shiv Sena was founded by Balasaheb Thackeray, as a political party based on the ethnic group of the Maharathi. It was a sectarian and xenophobic urban movement, hostile to immigrants from other Indian States and Muslims. Although rooted in Maharashtra, the Shiva Sena spread widely and became a national party of the Hindu Right. In 1984 Bajrang Dal ${ }^{14}$ was founded as the youth organization arm of the VHP. When regular demonstrations for the 're-conquest' of the holy site of Ayodhya took place and tensions between the religious communities grew, monks marching in procession needed protection. The Bajrang Dal soon became the 'military arm' of Hindu Nationalism.

At least two political parties have been directly inspired by Hindu Nationalism: the Bharatiya Jana Sangh (BJS) ${ }^{15}$ and Bharatiya Janata Party (BJP). ${ }^{16}$ Within the INC Vallabhbhai Patel was the leader whom Hindu nationalists look to as their point of reference. After his death (1950), Syama Prasad Mukherjee, former minister of Industry in the first government, remained the only politician who represented the Hindu Nationalist Movement. Mukherjee resigned after the so-called Delhi Pact, signed along with Pakistan, guaranteeing the rights of the minorities in both countries. He stated that Indians could not forget the violence during and after Partition, for which he blamed Pakistan. He was a member of RSS since 1942. After he had consulted Guru-ji, he formed the BJS. The formation of the BJS was proven positive that nationalist Hindus no longer trusted the INC (see Graham 1993). In 1952 the BJS won only three seats.

While the Hindu Nationalist Movement was working the grassroots, thanks to the organizational skills of the leader Deendayal Upadhyaya, the BJS grew and spread. In 1957 it won four seats. In 1962 14. In 1967 35. When early elections took place in 1971, the BJS won 22 seats. However during the Internal Emergency (1975-1977) the RSS, a potential ally of the opposition, was banned. As a result the Sangh was forced underground and the BJS became part of the Janata Party, the opposition coalition. At the 1977 elections the BJS won 94 seats in Parliament. But the cabinet, chaired by Morarji Desai and supported by a heterogeneous coalition, fell after two years. The Government repression during the 'emergency' meant that the Hindu Nationalist Movement was under attack. The BJS had to give up its own identity to mingle in the coalition, which held to Gandhian and liberal principles. Atal Bihari Vajpayee and Lal Krishna Advani, leaders of BJS, became respectively the External Affairs Minister and Information and Broadcasting Minister in the Desai cabinet. Jaffrelot called those years the "impossible assimilation". Locally the party and the movement remained faithful to the cause. While communal riots between Hindus and Muslims continued, the coalition demanded that the BJS sever its links to RSS. The party refused. After the fall of the Desai cabinet and elections with poor results a new nationalist party, the BJP, was formed. A new party in which the same leaders and militants held office. Vajpayee was chairman again. The violent national climate pushed the leadership towards a more moderate line in order to gain wider consensus. Emphasizing the Gandhian values and Pandit Upadhyaya's doctrine of Integral Humanism rather than the communal issues. The results of the 1984 elections, held during the turmoil that followed Indira Gandhi's murder, resulted in victory for the INC. The BJP won only two seats. Since then the party without question has been connected to the Hindu Nationalist Movement.

13 The World Hindu Council.

14 The Army of the Strong One. The Strong One (Bajrang) is the god Hanuman. Hanuman with monkey features is linked to Rama by a devoted love. While the figure of Rama has been changed to a warlike god, the same transformation involved Hanuman, traditionally represented with Rama's face in his chest, on his heart. Rama has become, more than the goddesses Kali or Durga, the god of the angry Hindus. So Hanuman has been deprived of his friendly and devotional features to emphasize his height, muscles, strength, and the huge cudgel he brandishes.

15 The Indian People's Association.

16 The Indian People's Party. 


\subsection{Pandit Deendayal Upadhyaya}

The BJS and later the BJP referred to the Integral Humanism of Deendayal Upadhyaya (1916-1968). "India after Independence has produced few leaders who were also political philosophers. Deendayalji was one of the few, and the finest." wrote Advani in his autobiography (Advani 2008, p. 150). Upadhyaya named his doctrine as he did because he aimed at developing all aspects of the human being: the body, the mind, the intellect, the soul (Sharma 2015). Pragmatic in politics and the economy, though he saw devolution based on the economic self-sufficiency of the rural villages as the key for India's progress. He said:

We are pledged to the service not of any particular community or section but of the entire nation. Every countryman is blood of our blood and flesh of our flesh. We shall not rest till we are able to give to every one of them a sense of pride that they are children of Bharatmata. We shall make Mother India Sujala, Suphala (overflowing with water and laden with fruits) in the real sense of these words. ${ }^{17}$

Orphan of a humble Indian Railways office worker from a little village near the holy city of Mathura (Uttar Pradesh), the portrait his devotees gave of him was modeled to that of Mahatma Gandhi. Stern, almost ascetic, though not lacking a sense of humor. Able to get his hands dirty with practical work and apply himself. He washed his clothes himself and was a great visionary. A great organizer and an acute thinker. Considered the 'mind' of BJS when it achieved remarkable electoral successes against the mighty INC. Upadhyaya's vision remains at the core of BJP ideology: a modern synthesis for today's Hindu Nationalism. ${ }^{18}$ Thanks to his knowledge of Western culture and history, he was scathing in his criticism of the contradictions and weaknesses inherent in the West. He contended that the great ideas of democracy, nationalism, socialism, peace, world unity, secularism (he defined them '-isms') mutually annihilate each other. Whereas Integral Humanism is India's universal mission, it is the completeness of a civilization realized over millennia, and at the same time the remedy to rid humanity of its evils. Humanism seemed to oppose any form of obscurantism, pointing at a truth which is deeper than any religion or any ideology. That is Dharma. Notwithstanding such humanism contains the presuppositions of a new intolerance and sectarianism. Upadhyaya, who was close to Golwalkar, denied any identification of Dharma with religion, rejected any kind of theocracy, offered the genuine secularism, affirmed a solidarity which goes beyond the borders of the communities. But his thinking is authoritarian. As a matter of fact his goal is not a theocracy but a 'Dharmacracy': a regime of Truth, indeed. Dharma is universal law and eternal wisdom. Moreover in that universal wisdom we find a paradox: tolerance would be part of it. Integral Humanism seems to propose the genuine secularism because Dharma is beyond any religion and philosophy, so it would not be sectarian. But while Upadhyaya proposes the Dharma Rajya (the Dharma Kingdom) as the supreme political ideal, he actually affirms the supremacy of a Truth above any other, a political system based on unconditioned and absolute values regulatory of every human choice.

The West is disowned because it is not capable of leading or directing the world. It has an illusory positive vision of life and the world, which has determined the debasement of humankind. Once again India finds itself the spiritual guide and mentor of humanity. Thus Integral Humanism becomes a sort of nationalism: India heralds the Truth. The universal Dharma opposes all religions. Religions live in history and in peoples' cultures (that is to say in a contingent dimension). India, with its Dharma, seen in its metaphysical dimension is the Guru of nations.

17 Cfr. http:/ / deendayalupadhyay.org/hindu.html (accessed on 7 July 2017).

18 Cfr. the lectures he delivered in a BJS retreat in 1965. http://www.bjp.org/about-the-party/philosophy/?u=integralhumanism (accessed on 14 August 2017). 


\section{Ayodhya, Shah Bano Case and Reservation Policy}

The scant electoral achievement for Vajpayee's moderate line led to rapid change. Within the BJP Lal Krishna Advani was appointed party President. Under his leadership it became the voice of the Ram Janmabhoomi Movement, the movement whose aim was the "reclaim" of the Ayodhya site. That old quarrel over a sacred site, never smoothed over, suddenly reaches the status of a symbol representing the tension between the major Indian religious communities. And, not least, a great chance to re-launch Hindu Nationalism's electoral prospects.

The Ayodhya mosque (Uttar Pradesh) was built by the Moghul emperor Babur on the site where according the tradition Rama was born. Ayodhya is an old city, celebrated in the Ramayana, containing many temples where Rama is worshipped. The city was captured in the 12th century by the first Muslim invaders and the holy place possibly desecrated, ruined and altered centuries before the Moghuls arrived. ${ }^{19}$ The Babri Masjid a noble and majestic building had a prestigious past. Its acoustics were legendary and it was revered as "the Mosque of the birthplace" (Masjid i Janmasthan). Both Hindus and Muslims worshiped there according to the Indian custom of worshipping a place just because it is holy. People believed that miraculous water poured into the pond nearby. But from the 1850s onwards, communal friction between Hindus and Muslims over who owned the holy site festered. Hindus from the Vaishnava tradition maintained their claim to the site, calling for the destruction of the mosque and the restoration of the Rama shrine. In December 1949 pious Hindus entered the temple during the night and placed statues of Rama and Sita in it. The faithful saw this as a miraculous apparition while Muslims saw it as blasphemy. So for reasons of public order the mosque was closed while the statues were not moved. At the beginning of the 1980s the VHP renewed its claim to the holy site. As often in India the dispute ended up in court. The BJP seized the opportunity to build on its popularity. The Ayodhya issue became the focus of the campaign for the 1989 elections in which they won 86 seats.

In order to understand why a local dispute, apparently irrelevant to national life, could have benefited a minor party and brought Hindutva to the center of public stage, one needs to examine the Shah Bano court case. Shah Bano, a Muslim woman of 62 disavowed by her husband in 1978 had been granted her right to alimony—denied by Islamic law-by the Supreme Court of India. The case prized open the issue of a universal civil code. Muslims complained. Parliament intervened. Under pressure from Muslim public opinion the verdict was overturned. As a consequence of the Muslims' backlash the Government enacted the Women (Protection of Rights on Divorce) Act (1986) that mitigated the Supreme Court verdict and de facto denied Muslim women the right to alimony. Rajiv Gandhi, then in power, worried that the Muslim support for INC would dwindle. In turn the Hindus complained of Muslim privilege. Many felt to be Hindu was to be discriminated against. However a later judgment of the Supreme Court interpreted the Act in a manner which reasserted the validity of the case and consequently upheld the Shah Bano judgment and The Women Act was nullified. Rajiv's conduct resulted in a loss of support from both camps of the sectarian divide. He encouraged traditionalist and zealous elements in the Muslim world, while creating disappointment in the Hindu community. Above all he frustrated the hopes for the establishment of a new, modern and enlightened governance. Again the principle of symmetry of treatment towards the different religious community was disregarded for political expediency.

1986 saw an Uttar Pradesh court rule that the Babri Masjid gates be reopened and Hindus permitted to worship inside providing a major boost to the Ram Janmabhoomi movement. It was not a simple and incautious judgment by a local magistrate. Many authors-among them Jaffrelot-argue that the judgment came after pressure from Delhi in order to appease the Hindu

19 The Muslims often converted Hindu temples into mosques, destroying statues and sculptures representing living beings or goddesses and using the stone as building material. 
majority. Thereby frustrating the Muslim minority even though the masjid had long been closed to them. The Rama Janmabhoomi Movement grew.

Another mass phenomenon resulted from the widespread availability of television in 1980s. Since 1987 the state public television broadcasting authority broadcast the epic poems of Ramayana and Mahabharata in weekly episodes attracting a massive audience. For the first time, every week at a certain time, Indians gathered en masse to watch their screens. The implicit and pervasive message conveyed by the programs was that Hindu mythology is the basis of Indian culture. The great poems ignited a revival of affection for the tradition. Many commentators connected this to the BJP subsequent political success.

On the 2nd of December 1989 V.P. Singh took the oath of the office as Prime Minister chairing a minority government propped-up by the opposition. Riots in Kashmir increased: the separatist movement (mainly Islamic) began an armed struggle. In 1989 the foundation stone for the new Rama temple at the Ayodhya site was laid. Riots broke out in Bangladesh and Pakistan, were Hindu temples were destroyed. In September 1990 L.K. Advani, a BJP leader, together with his then young acolyte Narendra Modi, began a pilgrimage (rath yatra) to Ayodhya across the country to generate support for the reclaim movement. Hindus across the world collected money for the construction of the new temple. The demonstrations, orchestrated by the BJP and Sangh Parivar, were seldom curtailed or repressed. Advani himself was arrested. The popularity of the BJP and the Hindutva grew.

While the Ayodhya masjid was under siege another controversy contributed to spoil social harmony. V.P. Singh contemplated the possibility of an extension of the Reservation Policy in order to increase acceptance of his vacillating government. ${ }^{20}$ The Reservation Policy had a quite limited implementation in the Indira Gandhi era and under the governments led by his son Rajiv Gandhi. It was a tool just locally used. In the 1990s an attempt was made to use it as an instrument to achieve a better political consensus, which brought about serious social and political destabilization.

That was (and remains even today) a sensitive issue: the Civil Service being the natural home for the higher castes, the increase in the number of posts reserved for the 'backward' and the 'other backward' classes would result in a contraction of jobs available to the established pecking order. Locally, some politicians had used the Reservation Policy to increase their political clout. The reaction emanating from the prominent castes had historically been, and was, harsh and violent. In the 1970s there were riots in Bihar and in the 1980s in Gujarat. The violence was aimed at the lower castes and the disadvantaged groups, perceived rightly or wrongly as competitors. Sometimes the violence was aimed at the Muslim minority. The social conflict among the castes assumed a religious dimension. At the beginning of the 1990s the Hindu Right backed the protest of the higher castes.

It could be argued that the spectacular political growth of Hindu Nationalism was due to the once dominant caste of the Brahmins, who were anxious to maintain their influence and wield power. Nonetheless the higher castes aspiration to salvage their privileges is likely to have played a role in the growth of Hindu Nationalism. Religious ideology in India rationalized the social structure and justified many unjust practices for centuries. Hindu Nationalism tends to legitimize the existing political and economical relationships (Torri 2002, p. 131). Thus the reaction of the higher classes was

20 The Nehruvian approach to inequality meant to solve the problem with initiatives aimed at disadvantage reduction (a series of affirmative action measures such as reserving access to seats in the various elected bodies, to government jobs, and to enrolment in higher educational institutions). Thus, according to the Constitution, at the beginning some historically backward groups could enjoy such a policy: they were the dalits (untouchables: 15\% of population) and the adivasis (tribal groups: 7.5\%), the so-called "Scheduled Castes" and "Scheduled Tribes" (SCs and STs). But afterwards, other backward groups, aware of their electoral importance, started gradually claiming benefits. But the "Other Backward Classes" (OBC) constitutes a mass of half the entire population. If all those groups could enjoy, for instance, the Reservation Policy the social balance would be seriously overturned and the policy itself would be no longer sustainable. In addition, how can the State identify such 'disadvantaged' groups? The capability of claiming the benefits they strive for shows their means, their political connections, their lobbying ability: their new power rather than their backwardness (d'Orazi Flavoni 2000). The first rulers following Independence were well aware of the complications that might arise from a Reservation Policy. To get an idea of the scale involved the Commission, chaired by B.P. Mandal, estimated that three millions jobs in the civil service would have to be reserved for the lower castes out of a workforce of 20 million. 
clamorous. Demonstrations against the Reservation Policy multiplied, with a new form of protest: several young boys set themselves on fire.

On 6 December 1992 the Babri Masjid was stormed by a mob who, with their bare hands, dismantled it. Advani recounts about that memorable day: "As every student of India's contemporary history will attest to, its impact on our society and polity-indeed, on our sense of national identity-has been tremendous." It was one of the great moments of history. India's soul spoke (Advani 2008, pp. 341-409). The victorious final attack to what was viewed as the symbol of the past Muslim oppression triggered a series of violent riots and anti-Muslim pogroms halted only after the Bombay bombing outrage of 12 March 1993.

\section{Victory!}

Why did the demand for the construction—rather, reconstruction-of a temple at Ramjanmabhoomi in Ayodhya gain such unprecedented support from the Hindu society? Why did it give rise to the biggest mass movement, with pan-national appeal, in the history of independent India? Why were hopes believed for the peaceful, lawful and amicable resolution of an issue that had needlessly been converted into a divisive Hindu vs. Muslim dispute? Did not the Congress party play a duplicitous role in the events that led to the demolition of the Babri structure on 6 December 1992-and also to the construction of a proto-temple of Lord Ram in Ayodhya? (Advani 2008, p. 342)

The Ayodhya case, according to Advani, is not only a quarrel about the reconstruction of the Ramjanmabhoomi temple. ${ }^{21}$ It is also the symbol of the long time struggle between genuine and fake secularism ("pseudo-secularism": Advani 2008, p. 367). And it is connected to the polarized debate between two opposite conceptions of the roots of India's national identity: the unifying concept of "cultural nationalism" and the divisive concept of anti-Hindu nationalism. In a long article published in two parts in "Indian Express", December 27 and 28, 1992, Advani highlighted the Ayodhya case: "the largest mass movement since independence" was not only a movement to reclaim a holy place, but also a reaffirmation of the national identity. To argue that it was an attack on secularism was slanderous. Advani asserted that secularism means pantha-santa-bhava, that is to say equal respect for each religion. He argued that India is secular solely because of its Hindu majority. A theocracy would be alien to Indian tradition and history. Indian Nationalism, just as the struggle for independence from British colonialism, is rooted in the Hindu ethos. ${ }^{22}$ Gandhi-ji himself pointed out the Rama Rajya ${ }^{23}$ is the goal of the independence movement. But that for forty years, using the guise of secularism, politicians wished to disavow the Nation's essential identity.

Advani spoke about the "distortion and perversion that has taken place in the concept of secularism". The INC secularism has degenerated into "sadist-secularism". Secularism was interpreted as irreligious and anti-religious, almost always as anti-Hindu (Advani 2008, pp. 857-59).

Indian secularism-he writes-has its roots in religion-in the Hindu view that all roads lead to God, as enunciated in the Vedic dictum 'Ekam Sat Vipraha Bahudha Vadanti' (Truth is one; the wise interpret it differently). [ ... ] The culture of any ancient nation is bound to be composite. But in our country, emphasis on the composite character of Indian culture is

21 The Ayodhya case is far from being solved: a judgment of the High Court of Allahabad in 2010 stated that the site is the real Rama's birthplace, the 'structure' was built by Emperor Babur, but it had not the features of a mosque. The judgment also recognized three parties to the dispute: the Muslims, the Hindus and a Vaishnava school, the Nirmohi Akhara. They are joint owners of the site, which must be used for cult purposes. It is easy to understand that such a verdict cannot stop the quarrel.

22 Advani often speaks about Hindu ethos, which is almost equivalent of chiti as Upadhyaya intended that concept. See Advani's speech at BJP national executive committee meeting on 24 November 2004, when he spoke of preserving the Hindu ethos to strengthen secularism and unity of India. "India is secular principally because of its Hindu ethos. [ ... ] If anybody tries to take the cover of secularism to indulge in anti-Hindu politics and statecraft, the BJP will stand in their path like a rock, prepared to make any sacrifices". (http://www.bjp.org/Press/nov_2404.htm, accessed on 13 November 2006)

23 Rama is the epitome of the good king, who rules according to the Dharma. 
generally an attempt to disown its essentially Hindu content. [ ... ] Hinduism remains by far the most powerful and pervasive element in that culture. (Advani 2008, p. 861)

\section{Religion and Violence}

In order to understand the reverberations of the mentioned events in social and cultural spheres we should now take into account an important easy by Peter van der Veer. He suggests that both riots and rituals are "comparable in their organization of symbolic space, in their temporal structure and in their symbolic repertoire" (van der Veer 1996, p. 154). Riots and rituals both appear to play a role in the construction of communal identities in public space. Ritual processions often end in full-scale riots. I mentioned the formation of RSS in the turmoil of the 1920s. There are "rituals of provocation". ${ }^{24}$

I want to suggest that riots provide a ritual space in which subjectivity, and its relation to state power, is discursively constructed. Public space does not only pattern ideas of community, but is itself, to an important extent, constructed through ritual and rioting. The special factor is as much a result as a basis of conceptions of community (van der Veer 1996, p. 155).

See the function of integration and national identification of the pilgrimages: pilgrimage plays a role in nation-building reinforcing the notion of a wider community of believers. Violent antagonism too may be a powerful mechanism of integration. "It is through the construction and maintenance of boundaries between "us" and "them" that group identities are shaped" (van der Veer 1996, p. 156).

On 27 February 2002 the Sabarmati Express stops at Godhra railway station (Gujarat). It is crowded with VHP militants, Hindu pilgrims, women and children returning home after a pilgrimage to Ayodhya. Poor Muslims live around the station. Some of the peddlers are Muslim. The atmosphere is tense. What really happens during the following minutes is still not clear. Violence breaks out. The train starts and stops. Muslims and Hindus begin to throw stones at each other. When the train starts again coach S-6 is on fire. 59 Hindus, among them 14 children, are burned alive. The fire is fed by luggage and gas canisters the pilgrims carried to cook food with during the long journey. The possibility of an accidental fire is rejected by the subsequent official inquiries. ${ }^{25}$ However, Muslims are generally held to be responsible for the outrage. Which in the hours immediately following the carnage triggers a massacre the dimensions of which are not fully known. Entire families are murdered and settlements destroyed, the final death toll is unknown. Reports speak of 800 Muslim and 250 Hindu deaths and at least 250 people missing. There is even talk of 5000 victims. Damage to houses, shops, factories, workshops, places of worship, is massive. Such destruction it would appear sought to eradicate Muslims from the state of Gujarat. The displaced number tens of thousands.

The Prime Minister of Gujarat was Narendra Modi, now India's Prime Minister. L.K. Advani was Minister of the Interior in the federal government. But the highest-ranking politician involved in the trial following the riot was Ms. Maya Kodnani, a minister in Modi's local cabinet. She was convicted in 2009, along with several Bajrang Dal militants, of the slaughter of Muslims at the settlement of Naroda Patiya, a suburb of Ahmedabad, in which 97 Muslims died, mainly women and children. In the anti-Muslim pogrom in Gujarat were in fact targeted key Muslim figures, commercial districts, along with women and children. The cruelty and the savagery of the slaughter of women and children must have been trigged by fear and rage. Fear of the 'foreign body', the enemy within, fear of being one day overcome by a growing privileged minority and of the change in the "religious demography"

24 Here van der Veer quote a work of Gaborieau: Gaborieau, March 1985. From Al-Beruni to Jinnah: Idiom, ritual and ideology of the Hindu-Muslim confrontation in South Asia. Anthropology Today, I/3: 7-14.

25 Martha C. Nussbaum reported an accurate reconstruction of the events and of the judicial and independent inquiries which follow. At least until her book is published (Nussbaum 2007, pp. 47-88). The most thorough and wide independent investigation has been conducted by the magazine Tehelka, specialised in investigative reports, that collected a large amount of evidences which reveal the involvement of local politicians, police authorities, and nationalist militants in the events of February-March 2002 and their attempt to affect the investigations. Cfr. (Ketan 2011). 
of India. Rage at being overwhelmed by conversions and by a rapidly increasing birth rate. Fear that Islamic fertility would prevail. Killing women means the killing of one's enemy's life. Killing children and the yet unborn is killing the enemies of tomorrow.

In Kandhamal District, Orissa (now Odisha), tensions between Hindus and Christians were frequent following claims over violations of the Scheduled Caste and the Scheduled Tribes (Prevention of Atrocities) Act: occupation of tribal land, illegal building of places of worship (mostly Christian) on tribal land, religious conversions (to Christianity), and exploiting tribals for insurgent activities which had resulted in riots in 1986, 1994 and 2001. Behind the clashes laid simmering tensions between equally impoverished tribes: the majority, the Kandha tribe, and the Pana. The Panas converted to Christianity in large numbers and some, supported by Christian Churches, prospered. Hindu nationalist groups blamed the Churches for using violence or "fraudulent means" to obtain conversions. The killing of the Australian missionary Graham Staines and his children can be seen against that backdrop of religious rivalry. On the night of 22 January 1999, he was sleeping in his station wagon when it is set alight. Graham and his two sons (10 and 6) were murdered. Dara Singh, a Hindu militant, was arrested and sentenced along with 12 others to life imprisonment for the murders. Although Dara Singh was a member of Bajrang Dal, the Wadhwa Commission ${ }^{26}$ ruled that there was no involvement of any organization in the crime.

In December 2007, Christians set a Christmas arch across the road and pitched a tent in the town of Brahmanigaon (Kandhamal District). On 24 December a large group of Hindus demanded the arch and the tent be removed, arguing that they were erected on the same site used by Hindus to celebrate the Durga Puja festival in October. The Hindu militants wanted the market to be closed and the Christian shopkeepers refused to comply: more than 20 shops were destroyed and three people killed. Further violence was reported in subsequent days in Phiringia, Godapur, Khajuripada, Gochapada, Barakhama, resulting in a further 50 Christians victims; 730 houses and 95 churches were set on fire. On the evening of 23 August 2008, the VHP member Swami Lakshmanananda Saraswati-an elderly Hindu monk committed to the reconversion of tribal people-was killed along with other VHP leaders and a boy. The gunmen might have been Maoist guerrillas who were very active in the District. Mobs allegedly incited by politicians from the BJP set fire to many Christian settlements. At least 45 people were killed, while Christian homes, churches and shops were destroyed. On 9 September the Maoists issued a press release claiming responsibility for the killing of Swami Lakshmanananda. Yet the violence continued.

Across the country Christian priests and pastors, nuns, members of religious congregations, catechists, preachers, volunteers have been targeted for decades by Hindu fundamentalists. Conversion of tribals or dalits to Christianity is often the reason of such violence. ${ }^{27}$ The lower castes' departure from Hindu ranks is seen as an attack on Hinduism. As a matter of fact the social work undertaken by Christian denominations among the more destitute challenges the traditional relations among the castes. Thus dominant caste members, moneylenders, landlords, police officer, along with local politicians and nationalist militants stand together in opposition to any threat to traditional hierarchy and religious orthodoxy.

26 Appointed by the Ministry of Home Affairs of the central Government to inquiry with respect to the facts and circumstances relating to the killing.

27 The debate on conversion has always been wide and passionate. To explain how the issue is experienced in India I give just an example: stated that freedom of faith includes not only freedom to practice one's faith but also to preach it to others, the intellectual Sudheendra Kulkarni, a moderate sympathizer of Hindutva, wrote: "Does my personal right to convert to another faith also mean that I should have the freedom to convert others? In large number? In an organized manner by making it my mission? By using foreign funds, coming from sources whose hidden—or not-so-hidden-purpose is to ensure a significant change in the religious demography of India, to begin with some states, some districts? Should I have the untrammeled freedom to use these funds to start anti-poverty projects in poor areas and make the seva [unselfish service] so rendered the core of my conversion appeal to the needy beneficiaries? By telling them that you cannot be "saved" but by joining my faith? [ ... ] Does religious freedom also mean that I should have the freedom to belittle or denigrate other faiths?" (Kulkarni, Sudheendra. Debating the right to convert. Indian Express, 5 October 2008). 
Clashes between the Hindus and Muslims in Muzaffarnagar District (Uttar Pradesh), during August and September 2013 resulted in at least 62 deaths 93 injured with more than 50,000 displaced. The riot involving two communities, the Hindu caste of Jats and Muslims, broke out on 27 August 2013. What caused this riot is still disputed: a minor traffic accident, sexual harassment, or a mixture of the two. A family quarrel resulted in the murder of a young Muslim man. Two Hindu brothers rumored to be the killers were lynched by a Muslim mob. News of the killings spread across the District. Local politicians urge and instigate retaliation. Clashes between the two communities continued with the exacting of vengeance over the next few weeks and resulting in dozens of victims. Despite a curfew and the intervention of the Army, clashes continued. Less than one year later, in May 2014, in the general elections BJP won in the constituency of Muzaffarnagar. Amit Shah, the BJP President, delivered an inflammatory speech during the campaign, calling for 'revenge' for the humiliation of the riot. "A man can live without food or sleep. He can live when he is thirsty and hungry. But when he is insulted, he cannot live. The humiliation has to be avenged." he said. Therefore to vote for the BJP is to be avenged.

\section{The Challenge}

Alberto Pelissero states that Hindu Nationalism has much more to do with politics than religion (Pelissero 2003). "Expressed in the simplest terms, the ideal of the Sangh is to carry the nation to the pinnacle of glory, through organizing the entire society and ensuring protection of Hindu Dharma", the RSS official website states. The preoccupation for organization, discipline, character building frequently appears in the texts and speeches of contemporary Hindu Nationalism. Some scholars hold that Hindutva is a movement away from the caste politics (see Kanungo 2002). Savarkar plays down the importance of caste: it is merely an institution of Indian civilization. What really counts is the nation - not the caste-and the fulfillment of what Upadhyaya would have called chiti (the soul of the nation). Most Authors, on the other hand, underline conservatism of Hindutva in social and economic domains. Thus to diminish the significance of the Caste System aims at lessening those factors-like caste- - that prevent from creating a larger Hindu identity. The riot of Muzaffarnagar, erupted against a backdrop of mostly peaceful coexistence, proved to be a very useful ploy to polarize both Hindu and Muslim communities such that identity is asserted through violent antagonism, tightening Hindu ranks against the 'Enemy'.

The text of a Golwalkar lecture about the "ordinary swayamsevak" can be found on the RSS website. $^{28}$ Why all the efforts and the commitment, the daily discipline and the unceasing labor required by the Sangh? Guru-ji wondered. For the Sangh's growth? The Sangh has already grown a lot. Occasionally, its name also figures in the newspapers. So the urgent objective is not to evolve a small organization within the Hindu Society. "In fact, our goal is to organize the entire Hindu Society".

Why all this urgency? The reason is obvious: the sorrowful condition of our Hindu society is there before us. It has forgotten its national identity. We have lost courage of conviction of calling our country, our nation as our own. Our love for the motherland appears to have been weakened. As a result, selfishness has become rampant in our society, coupled with the growth of vices, groupism, unethical behavior and vying with each other. It looks as though the whole society is getting disintegrated. In addition, many enemies have also infiltrated into our country. They are not leaving out any opportunity to disintegrate and destroy our society, and help their internal agents here. They are also standing on all sides of our boundary and nobody knows when they might attack. Further, vices such as mutual quarrels and feuds, lack of character, self-forgetfulness prevalent everywhere may well lead us to anarchy. If our internal fragmented situation further continues, we may lose our ability to resist the aggression of all these enemies when they attack.

28 http://rss.org//Encyc/2012/10/22/swayamsevak-know-rss.html (accessed on 28 July 2017). 
It is likely that without Moghul and British domination Hinduism would not have acquired such an ideological and militant identity (see Jaffrelot 1999). Hindus did not have a single orthodoxy, a hierarchical organization, they were not sufficiently aware of the 'Other' to be thoroughly self-conscious. Thus it was the epiphany of well armed, powerful others (that is to say the other as antagonist) which generated frustration and fear to such an extent that a kind of nationalism was born. With that perspective one can understand the efforts of the great native reformers of the 19th century onwards to elaborate a new image of Hinduism (Ram Mohan Roy, Dayananda Saraswati, Aurobindo, Vivekananda, Tagore)— the 'authentic' Hinduism, pure, rational, free from idolatry and aberrant customs - or the attempt of the 'gurus of hate ${ }^{29}$ to propose a 'national' Hinduism, homogeneous, syncretistic and with a paramilitary organization.

The coming into being of movements like the Hindu Mahasabha and the RSS could be seen as a reaction to the threat to Hindu identity from two different entities, both secular, the British Raj and the INC. The VHP, with a more religious profile, was founded with the goal of outlining an all-inclusive and general definition of Hinduism, suitable for each Hindu, able to recoup dalits and tribals and attract the secularized and with the goal of converting Muslims and Christians. A modern and coherent version of Hinduism, with a 'backbone'. The goal is unifying and organizing a 'Hindu Society', which is actually a vast and complex entity seldom disjointed or fragmented. Hindu Society can be realized only by the removal of the inner differences and the offering of a simple pattern, a homogeneous behavior, an undemanding truth.

Nehru, who followed the rational secular tradition, was conscious that his political opponents were the Right and Hindu Nationalism and reacted by emphasizing the secular character of the State and the defense of the minorities. But here lay a weakness in his thinking, Nehru too thought of India as a pluralistic and tolerant country, just as Gandhi did, where each and everyone could enjoy the same rights. But Nehru was skeptical of Gandhi's vision of politics based on religion. The Pandit made the same mistake as the secular intellectuals of the 20th century: believing religion was a kind of burden of the past. Science, technology, democracy, education—in one word modernity-would bring about progress and overcome the remains of the past. He trusted that a national political culture based on pluralism and tolerance would become the foundations of the new society. This is exactly what Hindu Nationalism takes issue with: the 'pseudo-seculars' project of building the national identity without Hinduism or against Hinduism.

Martha C. Nussbaum writes:

His [of Nehru] disdain for religion, together with his idea of a modernity based upon scientific rather than humanistic values, led to what was perhaps the most serious defect in the new nation: the failure to create a liberal-pluralistic public rhetorical and imaginative culture whose ideas could have worked at the grassroots level to oppose those of the Hindu right (Nussbaum 2007, p. 82).

So, two concepts of India- one based on ethos and blood, the other based on ethic and a shared political culture-collide. The contradictions and the difficulties of an incomplete secularism did the rest. India is not giving up on religion any time soon. Secularism and laicism run the risk of remaining 'politically correct' but with an extremely limited appeal to Indians. Secularism as a sort of modern snobbery. ${ }^{30}$ Nonetheless the real confrontation is between Hindutva and Hinduism and has been for a century (Battaglia 2015, 2017). Who exactly is a Hindu remains unclear even though Hindutva continues to answer the question in very simplified terms. Hinduness looks to be nothing but a slogan. But religion continues to play a role in the life of the nation, influencing the electoral process and

29 The great Indian historian Ramachandra Guha called Golwalkar "the guru of hate". Cfr. R. Guha, The guru of hate, The Hindu 26 November 2006.

30 See the reflections of the Indian intellectual S. Visvanathan about the victory of BJP at 2014 elections: How Modi defeated liberals like me, in The Hindu, 26 May 2014. 
determining political success. India has spoken in the last elections and granted the victory to the party inspired by Hindutva. Since the Nation's will is the expression of the chiti, Dharmacracy is at a hand.

Conflicts of Interest: The author declares no conflict of interest.

\section{Bibliography}

Anderson, Benedict. 1983. Imagined Communities. Reflections on the Origin and Spread of Nationalism. London and New York: Verso Books.

Appaiah, Parvathy. 2003. Hindutva. In Ideology and Politics. Delhi: Deep \& Deep.

Basu, Tapan, Pradip Datta, Sumit Sarkar, Tanika Sarkar, and Sambuddha Sen. 1993. Khaki Shorts, Safron Flags. A Critique of the Hindu Right. Delhi: Orient Longman.

Battaglia, Gino. 2017. Hindutva: O fundamentalismo nacional-religioso na Índia contemporânea. In Fundamentalismos Reliogiosos, Violência e Sociedade. Edited by Enzo Pace, Irene Dias de Oliveira and Marion Aubrée. São Pualo: Fonte Editorial-Edições Terceira Via.

Bhatt, Chetan. 2001. Hindu Nationalism. Origins, Ideologies and Modern Myths. Oxford and New York: Berg.

Chatterjee, Partha. 1997. A Possible India. Essays in Political Criticism. New Delhi: Oxford University Press.

Chatterji, Angana P. 2009. Violent Gods: Hindu Nationalism in India's Present. Narratives from Orissa. Gurgaon: Three Essays Collective.

Chitkara, Madan G. 2003. Hindutva Parivar. New Delhi: APH Publishing Corporation.

Chopra, P.N. 1998. Religions and Communities of India. New Delhi and Bombay and Hyderabad: Vision Books.

Fernandes, Edna. 2007. Holy Warriors. A Journey into the Heart of Indian Fundamentalism. London: Portobello Books.

Giorda, Maria Chiara, ed. 2012. Dio lo Vuole! I Fondamentalismi Religiosi. Torino: SEI.

Gosh, Partha. 1999. BJP and the Evolution of Hindu Nationalism. From Periphery to Centre.

Delhi: Manohar.

Hansen, Thomas Bloom. 1999. The Saffron Wave. Democracy and Hindu Nationalism in Modern India. Princeton: Princeton University Press.

Kakar, Sudir. 1996. Indian Identity. New Delhi: Penguin Books.

Khetan, Ashish. 2011. Burning after reading. Tehelka Magazine 8/9.

Khilnani, Sunil. 1998. The Idea of India. London, New York, Victoria, Toronto and Aukland: Penguin Books.

Ludden, David, ed. 2007. Making India Hindu. Religion, Community, and the Politics of Democracy in India. New Delhi: Oxford University Press.

Noorani, Abdul Gafoor Abdul Majeed. 2000. The RSS and the BJP: A Division of Labour. Delhi: Leftword Books.

Sarkar, Sumit. 2002. Beyond Nationalist Frames. Postmodernism, Hindu Fundamentalism, History. Bloomington and Indianapolis: Indiana University Press.

Sarkar, Tanika. 2001. Hindu Wife, Hindu Nation: Religion, Community, Cultural Nationalism. Delhi: Permanent Black \& Indian University Press.

Sharma, Jyotirmaya. 2003. Hindutva. Exploring the Idea of Hindu Nationalism. New Delhi: Penguin—Viking.

\section{References}

Advani, Lal Krishna. 2008. My Country My Life. New Delhi: Rupa \& Co.

Almond, Gabriel A., Scott Appleby R., and Emmanuel Sivan. 2003. Strong Religion. The Rise of Fundamentalisms around the World. Chicago and London: The University of Chicago Press. 
Andersen, Walter K., and Shridar D. Damle. 1987. The Brotherhood in Saffron. The Rashtriya Swayamsevak Sangh and Hindu Revivalism. Delhi: Vistaar Publications.

Basu, Kaushik, and Sanjay Subrahmanyam, eds. 1996. Unravelling the Nation: Sectarian Conflict and India's Secular Identity. Delhi: Penguin Books.

Battaglia, Gino. 2015. L'altro Fondamentalismo. India, Nazionalismo, Identità. Napoli: Guida.

Battaglia, Gino. 2017. Lo Hindutva al potere. Nazione e religione nell'India contemporanea. La Critica Sociologica 51/201: 15-22.

Brugger, Winfried. 2009. From Hostility through Recognition to Identification: State-church Models and their Relations to Freedom of Religion. In Secularization and World Religions. Edited by Hans Joas and Klaus Wiegandt. Glasgow: Liverpool University Press, pp. 160-80.

Catalano, Roberto. 2009. Induismo fra arianizzazione, sanskritizzazione e debrahmanizzazione. Nuova Umanità XXXI: 437-71.

Chitkara, Madan G. 2004. Rashtriya Swayamsevak Sangh: National Upsurge. New Delhi: APH Publishing Corporation. d'Orazi Flavoni, Francesco. 2000. Storia dell'India. Società e Sistema Dall'indipendenza ad Oggi. Venezia: Marsilio.

Golwalkar, Madhav Sadashiv. 1939. We, or Our Nation defined. Nagpur: Bharat Publications.

Goyal, Des Raj. 1979. Rashtriya Swayamsevak Sangh. Delhi: Radha Krishna.

Graham, Bruce Desmond. 1993. Hindu Nationalism and Indian Politics. The Origins and Development of the Bharatiya Jana Sangh. New Delhi: Cambridge University Press.

Jaffrelot, Christophe. 1999. The Hindu National Movement and Indian Politics. 1925 to the 1990s. With New Afterword. New Delhi: Penguin Books India.

Kanungo, Pralay. 2002. Rss's Tryst with Politics: From Hedgewar to Sudarshan. Delhi: Manohar.

Kumar, G. Stanley Jaya, and B. V. Muralidhar, eds. 1997. Achieving Communal harmony and National Integration: A Dream for Every Indian. New Delhi: MD Publication PVT LTD.

Madan, Triloki Nath. 1998. Modern Myths. Locked Minds. Secularism and Fundamentalism in India. Delhi: Oxford University Press.

Naso, Paolo. 2015. L'incognita Post-Secolare. Pluralismo Religioso, Fondamentalismi, Laicità. Napoli: Guida.

Nussbaum, Martha C. 2007. The Clash Within. Democracy, Religious Violence, and India's Future. Cambridge and London: The Belknap Press of Harvard University Press.

Pace, Enzo, and Renzo Guolo. 2002. I Fondamentalismi. Roma and Bari: Laterza.

Pace, Enzo. 2004. Perché le Religioni Scendono in Guerra? Roma and Bari: Laterza.

Pace, Enzo. 2009. I Fondamentalismi nel Mondo Contemporaneo. Available online: http://www.treccani.it/ enciclopedia/i-fondamentalismi-nel-mondo-contemporaneo_(XXI-Secolo)/ (accessed on 8 July 2017).

Pelissero, Alberto. 2003. Fondamentalismo hindu: possibili ragioni, sviluppi insostenibili. In Guerre Globali. Capire $i$ Conflitti del XXI Secolo. Edited by Angelo d'Orsi. Roma: Carocci, pp. 181-89.

Puri, Balraj. 1987. Communalism and Regionalism. Economic \& Political Weekly 22: 1132-36.

Ruthven, Malise. 2007. Fundamentalism: A Very Short Introduction. Oxford: Oxford University Press.

Savarkar, Vinayak Damodar. 2005. Hindutva: Who is a Hindu? New Delhi: Hindi Sahitya Sadan. Frist published 1923.

Sen, Amartya. 2005. Secularism and Its Discontent. In The Argumentative Indian. Writings on Indian History, Culture and Identity. London: Penguin Books, pp. 294-316.

Sharma, Jyotirmaya. 2007. Terrifying Vision. M.S. Golwalkar, the RSS and India. New Delhi: Penguin-Viking.

Sharma, Mahesh Chandra. 2015. Pandit Deendayal Upadhyaya; New Delhi: Publications Division, Ministry of Information and Broadcasting, Government of India.

Smith, Donald Eugene. 1963. India as a Secular State. Princeton: Princeton University Press.

Srikanth, H. 1994. Secularism Versus Pseudo-Secularism: An Indian Debate. Social Action 44: 39-53.

Swamy, Subramanian. 2006. Hindus under Siege. The Way Out. New Delhi: Har-Anand Publications.

Tejani, Shabnum. 2008. Indian Secularism. A Social and Intellectual History, 1890-1950. Bloomington and Indianapolis: Indiana University Press.

Tharoor, Shashi. 1997. India: From Midnight to the Millennium. New Delhi: Penguin Books.

Torri, Michelguglielmo. 2002. Origine, evoluzione e trasformazione della democrazia indiana. In Il Subcontinente Indiano Verso il Terzo Millennio. Edited by Elisabetta Basile and Michelguglielmo Torri. Milano: Franco Angeli, pp. 77-145. 
Van der Veer, Peter. 1996. Riots and Rituals: The Construction of Violence and Public Space in Hindu Nationalism. In Riots and Pogroms. Edited by Paul R. Brass. New York: New York University Press, pp. 154-76.

Van der Veer, Peter. 2000. Religious Nationalism. Hindus and Muslims in India. New Delhi: Oxford University Press. Zakarya, Rafiq. 2002. Communal Rage in Secular India. Mumbai: Popular Prakashan.

(c) 2017 by the author. Licensee MDPI, Basel, Switzerland. This article is an open access article distributed under the terms and conditions of the Creative Commons Attribution (CC BY) license (http://creativecommons.org/licenses/by/4.0/). 